\title{
IMPACT OF SULPHUR AND BIOCHAR APPLICATIONS ON SOIL PROPERTIES AND PRODUCTIONS OF WHEAT AND SOYBEAN YIELDS IN SOILS HAVING TEXTURE
}

\author{
B. A. El-Gamal ${ }^{(1)}$, Naglaa E. Khalafallah ${ }^{(2)}$ and M. M. El-Kafrawy ${ }^{(1)}$ \\ ${ }^{(1)}$ Soils, Water and Environment Res. Inst. ARC, Giza, Egypt. \\ (2) Soil and water Dept., Fac., of Agric., Tanta University \\ * Corresponding author email: basher.elgamal12@gamil.com.
}

Received: Nov. 28, 2020

Accepted: Dec. 19, 2020

\begin{abstract}
Lysimeter experiments were conducted during two consecutive seasons of winter 2017/2018 and summer season 2018 for wheat and soybean at EL-Gemmieza Agriculture Research Station, El Gharbiya Governorate to study the influence of sulphur and biochar on soil proprieties, productivity of wheat and soybean yields in soils have different texture classes. The experiments were lay out in a split plot (SP) design with three replicates. The main plots were occupied with three different types of soils (clay, calcareous and sandy soils), sub plots were devoted to soil amendments i.e T1: control, T2: sulphur (1.50 Mg ha $\left.{ }^{-1}\right)$, T3: biochar $\left(5 \mathrm{Mg} \mathrm{ha}^{-1}\right)$ and T4: sulphur $\left(1.50 \mathrm{Mg} \mathrm{ha}^{-1}\right)+$ biochar $\left(5 \mathrm{Mg} \mathrm{ha}^{-1}\right)$. Results indicated that application of sulphur or biochar and individually and in combination led to an increase in available $\mathrm{N}, \mathrm{P}, \mathrm{K}$, cation exchange capacity, total porosity, organic matter, exchangeable $\mathrm{Ca}, \mathrm{Mg}$ and $\mathrm{K}$ while $\mathrm{EC}, \mathrm{pH}$, bulk density and soil hydraulic conductivity high significantly decreased in sandy and calcareous soils. On the contrary, soil hydraulic conductivity high significantly increased by different treatments in the clay soil. Grain and straw yields as well as $\mathrm{N}, \mathrm{P}$ and $\mathrm{K}$ concentration and uptake of wheat and soybean were high significantly increased by all application sulphur and biochar. Consequently the improvement of soil types on all properties can be arranged in the following order sandy soil < calcareous soil < clay soil. The combination application of biochar and sulphur (T4) lead to significant increase in yield of wheat and soybean (grain and straw).
\end{abstract}

Key words: Sandy soil, Calcareous soil, Clay soil, Wheat, Soybean, Sulphur, Biochar, Soil properties.

\section{INTRODUCTION}

In Egypt, wheat is considered as one of the most vital cereal crops in the human life because it is rich in mineral, gluten and fiber contents. The total production of wheat in Egypt was 8.4 million ton from a land area of 1.28 to 1.43 million hectare (FAO, 2011) and (Helmy and Shaban, 2013). At present, demand for soybeans is increasing because it is a major commercial crop that is grown around the world, and it is a major source of protein, oil, fiber, vitamins, minerals and nutrients. The seed of proteins contains $40-45 \%$ based on dry weight (Kaviani and Kharabian, 2008). Therefore, appropriate production technology as well as low-cost soybean production should be encouraged to improve soybean productivity. Because of rising prices for mineral fertilizers, low-cost organic adjustments are a convincing alternative to partial substitution.

Biochar is a porous and highly stable form of charcoal produced by slow down the pyramid movement of organic wastes such as crop residue. There is growing interest in their potential, especially as soil amendments and carbon 
sequestration. During the pyrolysis process, biomass is heated in a zero- or low-oxygen environment. The process generates three products; biochar, tar and syngas. The pyrolysis process retains carbon in the biomass in the form of biochar, instead of being converted to carbon dioxide as in regular combustion. (Verheijen et al., 2010, Kookana et al., 2011, and $\mathrm{Xu}$ et al., 2011,). The biochar (B) integration can change the physical properties of soil such as structure, total density and pore size distribution, water holding capacity, with implications for soil aeration, soil workability and increasing soil $\mathrm{C}$ storage on a large scale as well as improve plant growth. Application of biochar at 5 and 10 ton fed $^{-}$ 1 decreased soil bulk density (Bd), hydraulic conductivity( $\mathrm{Hc}), \mathrm{pH}, \mathrm{EC}$, soluble $\mathrm{Na}$, SAR and ESP values, while increased cation exchange capacity (CEC), organic matter, total nitrogen as well as available amounts of $\mathrm{P}, \mathrm{K}$. (Mousa, 2017).

Sulphur (S) is essential for the synthesis of proteins and vitamins and the containment of essential amino acids and vitamins, which is also associated with nitrogen metabolism. The good yield of wheat and soybean can be achieved by balanced and adequate supply of phosphate, sulphur and other deficient nutrients. The agricultural effectiveness of the reduced sulphur is directly related to the oxidation rate that provides the plant sulfate available after application. Elements sulphur are non-soluble hydrophobic particles based on the microbial colonization of their surface and the subsequent oxidation rates of sulphur are slow in cold and dry soils (Malhi et al., 2005). In addition to providing sulfur as a nutrient, sulfur compounds are also used as soil conditioners, these compounds act as soil acidifiers neutralizing $\mathrm{CaCO} 3$ with acid, thus can reduce soil $\mathrm{pH}$ and improve the availability of elements. Soil compaction rates required for plant response depend on the amount of $\mathrm{CaCO} 3$ in the soil (El-Tarabily et al., 2006). Calcareous soils are alkaline because of the presence of $\mathrm{CaCO}_{3}$ which dominates the soil physical and chemical properties. Many soil factors affect uptake of nutrient crops from soil. Among these factors, high $\mathrm{CaCO}_{3}$ and $\mathrm{pH}$ are often responsible for reducing the availability of crop nutrients (Kaya et al., 2009). Relatively low calcareous sandy soil in OM with high soil $\mathrm{pH}$ has shown a significant decrease on nutrients availability that provide growth Plant. (Abdou, 2006). The pH of soil has an important role to play in the loss of nitrogen or fixation of most nutrients, so different nutrient management practices are needed to produce crops in different soil types. Calcareous soil contains total calcium carbonate and soil $\mathrm{pH}$ which significantly reduces the availability of macro and micronutrients (Brady and Weil, 2002).

Sandy soils in Egypt are characterized by poor fertility (low retention capacity for water and nutrients) and limited crop productivity. Searching for natural organic amendments to improve their fertilities is one of the vital tasks in the Egyptian agriculture system (Ali, 2018). Wahab et al., (2010) found that a large area in the north of the Nile Delta was in great danger of physical and chemical degradation. Moreover, soil compaction, logging on water, alkaline, and salinity are very high in different land units. Therefore, the ameliorative impacts of biochar and sulphur on wheat and soybean yields and some soil properties were investigated under different soils.

\section{MATERIALS AND METHODS}

\section{Sampling Location:}

Three soil were used sandy, calcareous and clay soils. The sandy soil was collected from location of EL- 
Bostan- Bahira Governorate, the calcareous soil was taken from Kilo 48 cairo -Alexandria desert road -Nubaria Bahira Governorate, the clay soil was taken from EL-Gemmieza Agriculture Research Station, of the Agricultural Research Center (ARC), El Gharbiya Governorate. Three soils pot in thirty six lysimeters 2 meter in length, 1 meter in width and 2 meter in depth were used in this study.

\section{Experimental design}

Lysimeter experiments were conducted at EL-Gemmieza Agriculture Research Station, of the Agric., Res., Center (ARC), El Gharbiya Governorate, Egypt (Middle Delta region 30 43latitude and 31\% 47- longitude) during two successive growing winter season of $2017 / 2018$ and summer season of 2018. Thirty six lysimeters 2 meter in length, 1meter in width and 2 meter in depth. Lysimeters divided into three main groups, each group were filled with one of soil type namely: sandy, calcareous and clay soils. Each soil is considered as an independent experiment was designed as split plot (SP) with three replicates. The main groups were occupied by three soils (sandy, calcareous and clay soils). The lysimeters of each soil were deviled into four sub groups representing the studied treatments of sulphur (S) and biochar (B) which were T1: control (without any addition), T2: sulphur (1.50 $\left.\mathrm{Mg} \mathrm{ha}^{-1}\right)$, T3: biochar (5 $\mathrm{Mg} \mathrm{ha}^{-1}$ ) and T4: sulphur (1.50Mg ha-1) + biochar (5 Mg ha$\left.{ }^{1}\right)$. S and B were thoroughly blended with the surface soil layer $(0-30 \mathrm{~cm})$ of the concerned plots before wheat planting.

The study started in winter growing season 2017/2018 with Wheat (Triticum aestivum $L$ Giza 168) by using $120 \mathrm{Kg} \mathrm{ha}^{-1}$ grains rate, grains were cultivated on $24^{\text {th }}$ November 2017. The recommended doses of mineral NPK fertilizers were applied as recommended by the Ministry of Agriculture, Egypt. Super phosphate $\left(15.5 \% \mathrm{P}_{2} \mathrm{O}_{5}\right)$ was added as a single dose at rate of $230 \mathrm{~kg} \mathrm{ha}^{-1}$ before cultivation and mixed in the same times with such surface layer. $\mathbf{N}$ fertilizer was used as ammonium nitrate $\left(\mathrm{NH}_{4} \mathrm{NO}_{3}\right)(33.5 \% \mathrm{~N})$ at rate of $540 \mathrm{~kg} \mathrm{ha}^{-1}$ which added in three equal portions at heading stages and after 30 and 60 days of sowing. Potassium fertilizer was added at rate of $238 \mathrm{~kg} \mathrm{ha}^{-1}$ as Potassium sulphate $\left(\mathrm{K}_{2} \mathrm{SO}_{4}\right)\left(48 \% \mathrm{~K}_{2} \mathrm{O}\right)$, where applied after 60 and 90 days of sowing. Wheat plants was harvested at in $19^{\text {th }}$ May 2018. The grains separated from straw and weighted separately. The second growing season of 2018 followed the first, 5 seeds of soybean (Glycine max (L.) Merrill, Giza 111) were sown in a small whole; the distance between the wholes was $15 \mathrm{~cm}$. Soybean plants were thinned to 3 plants after their full germination. The other agricultural practices were done as the recommendation of Ministry of Agriculture. $P$ was added at rate of $460 \mathrm{~kg}$ $\mathrm{ha}^{-1}$ before cultivation as superphosphate $\left(15.5 \% \mathrm{P}_{2} \mathrm{O}_{5}\right)$. Nitrogen doses were added in equal three times at rate $450 \mathrm{Kg} \mathrm{ha}^{-1}$ as ammonium nitrate $\left(\mathrm{NH}_{4} \mathrm{NO}_{3}\right) \quad(33.5 \% \mathrm{~N})$ after 30 and 60 days of sowing. Potassium fertilizer was added at rate 238 $\mathrm{kg} \mathrm{ha}^{-1}$ was add as potassium sulphate $\left(48 \% \quad \mathrm{~K}_{2} \mathrm{O}\right)$ after 40 and 60 days of sowing. Soybean Plants were harvested on the $17^{\text {th }}$ of September 2018 and the grains were separated from straw and weighted separately. After harvesting of either of wheat and soybean soil sample of each experimental unit was taken and analyzed for soil physical and chemical properties as well as its available $\mathbf{N}$. P and $\mathrm{K}$. Before planting, soil samples were collected at the depth of $(0-30 \mathrm{~cm})$ from three different soils. Samples were allowed to dry under shade, then ground and sieved to pass through a $2 \mathrm{~mm}$ sieve. Each sample was stored in prepared plastic bags for subsequent laboratory analysis. soil samples were analyzed for some chemical characteristics according to Land and Development Department 
(2010) soil pH were determined in a 1:2.5 ratio (soil/water susp.), The total soluble salts (EC) were determined using electrical conductivity meter at $25^{\circ} \mathrm{C}$ in soil paste extract as $\mathrm{dS} \mathrm{m}^{-1}$, cation exchange capacity (CEC) were determined by using ammonium acetate. Organic matter (OM) were determined by using Walkley and Black method, the soil content of available $N, P$ and $K$ were extracted by $\mathrm{KCl}(2 \mathrm{M}), \mathrm{NaHCO}_{3}(0.5 \mathrm{M})$ and $\mathrm{CH}_{3} \mathrm{COONH}_{4}(1 \mathrm{M})$, respectively. Available $N, P$ and $K$ were determined according to the method of AOAC. (1995). Exchangeable calcium, magnesium, sodium and potassium were determined in $1 \mathrm{~N}$ ammonium acetate extraction at $\mathrm{pH}$ 7.0, where, $\mathrm{Na}$ and $\mathrm{K}$ were determined by flame photometry, while, $\mathrm{Ca}+\mathrm{Mg}$ were determined by EDTA titration. The content of calcium carbonate was determined by using calcimeter according to (Balazs et al., 2005). Particle size distribution was carried out by the Pipette method described by Sheldrick and Wang, (1993). Soil samples were taken from the three soils to determine the bulk density (Bd) according to Blake and Hartge, (1986), hydraulic conductivity
(Hc) was measured by auger hole method according to Rowell, (1995). The main physical and chemical properties of the three soils are presented in Table (1). This material which supplied by El-Help company, Egypt. Sulphur was applied to improve the soils. The biochar treatment used in this experiment at two years was prepared from different types of citrus trees. Chemical and physical properties of the used biochar were determined and the obtained data are showed in Table (2). For trapping $\mathrm{CO}_{2}$, vials containing 10 $\mathrm{ml}$ of $1 \mathrm{M} \mathrm{Na} \mathrm{OH}$ were placed inside vessels filled with $100 \mathrm{~g}$ of non and biochar treated soil samples having the moisture content at the field capacity. Then, the vessels were tightly closed and incubated under controlled conditions at $30^{\circ} \mathrm{C}$. This temperature was chosen because the optimal temperature for the microbial activity ranges from 20 to $35^{\circ} \mathrm{C}$. The $\mathrm{CO}_{2}$ evolved during each incubation period was trapped in $1 \mathrm{M} \mathrm{NaOH}$ and the excess of $\mathrm{NaOH}$ was titrated with $0.1 \mathrm{M}$ $\mathrm{HCl}$ after adding $\mathrm{BaCl}_{2}$. Mineralized $\mathrm{C}$ was calculated as a cumulative $\mathrm{CO}_{2}^{-}$evolution (g kg ${ }^{-1}$ soil) according to Leifeld et al., (2002).

Table (1): chemical and physical properties of the experimental soils.

\begin{tabular}{|c|c|c|c|c|c|c|c|c|c|c|c|c|}
\hline \multirow[t]{2}{*}{ Soils } & \multirow{2}{*}{$\begin{array}{c}\text { pH } \\
(1: 2.5)\end{array}$} & \multirow{2}{*}{$\begin{array}{c}E C \\
\left(d s ~^{-1}\right)\end{array}$} & \multicolumn{4}{|c|}{$\begin{array}{l}\text { Soluble cations } \\
\qquad\left(\mathrm{meq} \mathrm{L}^{-1}\right)\end{array}$} & \multicolumn{4}{|c|}{$\begin{array}{l}\text { Soluble anaions } \\
\qquad\left(\mathrm{meq} \mathrm{L}^{-1}\right)\end{array}$} & \multirow{2}{*}{$\begin{array}{l}\text { OM } \\
\text { (\%) }\end{array}$} & \multirow{2}{*}{$\begin{array}{c}\mathrm{CaCO}_{3} \\
(\%)\end{array}$} \\
\hline & & & $\mathrm{Ca}^{2+}$ & $\mathbf{M g}^{2+}$ & $\mathrm{Na}^{+}$ & $\mathrm{K}^{+}$ & $\mathrm{Cl}^{-}$ & $\mathrm{CO}_{3}^{--}$ & $\mathrm{HCO}_{3}$ & $\mathrm{SO}_{4}^{-}$ & & \\
\hline Sandy & 8.33 & 4.31 & 5.80 & 7.80 & 28.95 & 0.32 & 18.80 & ND & 7.95 & 16.12 & 0.25 & 4.80 \\
\hline Calcareous & 8.21 & 2.90 & 6.80 & 4.90 & 17.89 & 0.39 & 12.80 & ND & 6.00 & 11.18 & 0.38 & 26.11 \\
\hline Clay & 8.27 & 4.70 & 6.00 & 7.05 & 33.08 & 0.68 & 23.00 & ND & 8.75 & 15.06 & 0.69 & 3.10 \\
\hline
\end{tabular}

\begin{tabular}{|c|c|c|c|c|c|c|c|c|c|c|c|c|c|c|}
\hline \multirow{2}{*}{ Soils } & \multicolumn{4}{|c|}{$\begin{array}{c}\text { Exchangeable cations } \\
(\mathrm{cmol} \mathrm{Kg}\end{array}$} & \multirow{2}{*}{$\begin{array}{l}\text { CEC } \\
(\mathrm{cmol} \\
\left.\mathrm{Kg}^{-1}\right)\end{array}$} & \multirow{2}{*}{ ESP } & \multicolumn{4}{|c|}{ Particle size distribution } & \multirow[t]{2}{*}{ Texture } & \multirow[t]{2}{*}{$\begin{array}{c}\mathrm{Bd} \\
\left(\mathrm{g} \mathrm{cm}^{-3}\right)\end{array}$} & \multirow[t]{2}{*}{$\begin{array}{l}\text { Tp } \\
(\%)\end{array}$} & \multirow[t]{2}{*}{$\begin{array}{c}\mathrm{HC} \\
\mathrm{cm} \mathrm{hr}\end{array}$} \\
\hline & $\mathrm{Ca}^{2+}$ & $\mathbf{M g}^{2+}$ & $\mathrm{Na}^{+}$ & $\mathrm{K}^{+}$ & & & $\begin{array}{c}\text { C- } \\
\text { sand }\end{array}$ & $\begin{array}{l}\text { F- } \\
\text { sand }\end{array}$ & Silt & clay & & & & \\
\hline Sandy & 1.70 & 2.20 & 2.15 & 0.40 & 65.65 & 32.33 & 50.75 & 40.05 & 5.20 & 4.00 & sandy & 1.62 & 38.87 & 19.27 \\
\hline Calcareous & 7.00 & 4.40 & 4.00 & 0.70 & 16.80 & 23.81 & 20.45 & 22.80 & 30.71 & 26.04 & $\begin{array}{l}\text { sandy } \\
\text { loam }\end{array}$ & 1.49 & 43.77 & 10.01 \\
\hline
\end{tabular}




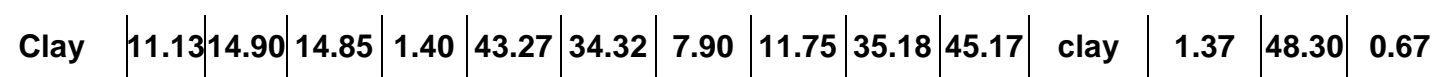

, $\mathrm{CEC}=$ Cation exchange capacity $\mathrm{OM}=$ Organic matter ESP= Exchangeable sodium percentage, $\mathrm{Bd}=$ bulk density, $\mathrm{Tp}=$ total porosity, $\mathrm{Hc}=$ Hydraulic conductivity

Table (2): Some characteristics of biochar used in this study.

\begin{tabular}{|c|c|c|c|c|c|c|c|c|c|}
\hline properties & $\begin{array}{c}\mathrm{pH} \\
(1: 10)\end{array}$ & $\begin{array}{c}\mathrm{EC} \\
(1: 10) \\
\mathrm{dS} \mathrm{m}^{-1}\end{array}$ & $\begin{array}{c}\text { CEC } \\
(\mathrm{Cmol} \\
\left.\mathrm{kg}^{-1}\right)\end{array}$ & $\begin{array}{c}\text { Bd } \\
\left(\mathrm{g} \mathrm{cm}^{-3}\right)\end{array}$ & $\begin{array}{c}\text { Total N } \\
(\%)\end{array}$ & $\begin{array}{c}\text { Total P } \\
(\%)\end{array}$ & $\begin{array}{c}\text { Total K } \\
(\%)\end{array}$ & OC (\%) & $\begin{array}{c}\mathrm{C} / \mathrm{N} \\
\text { ratio }\end{array}$ \\
\hline Biochar & 8.95 & 1.85 & 33.85 & 0.52 & 1.84 & 0.46 & 1.10 & 59.25 & 32.20 \\
\hline
\end{tabular}

Sample of biochar was air-dried and ground, $1.0 \mathrm{gm}$ weight of biochar and digested using mixture of $\mathrm{H}_{2} \mathrm{SO}_{4}$ and $\mathrm{HClO}_{4}$ at mixed rate of $3: 1$ Then, the digest was diluted with distilled water to a volume of $100 \mathrm{ml}$. Aliquots from this digest was analyzed for physical and chemical properties according to Blake and Hartge (1986) and Cottenie et al. (1982). Plant samples (grain and straw) of both wheat and soybean were oven dried at $70{ }^{\circ} \mathrm{C}$ and ground $\mathrm{A} 0.5 \mathrm{~g}$ of oven-dried plant sample was digested using $\mathrm{H}_{2} \mathrm{SO}_{4}$ and $\mathrm{HClO}_{4}$ mixture according to the method described by Chapman and Partt, (1961). In the final diluted digests of plant sample concentration $N, P$ and $K$ were determined according to methods described by (Cottenie et al., 1982).

\section{Statistical analysis:-}

The data were analyzed statistically according to the contrast analysis (ANOVA) to assess the impact of amendments on soil characteristics and wheat and soybean yield, which is the least significant difference (LSD) at the probability level of 0.05 applied to make comparisons among treatment means (SAS, 2010).

\section{RESULTS AND DISCUSSION}

I. Effects the sulphur (S) and biochar (B) application on soil chemical properties

\section{a: Soil pH and EC}

Results given in Table (3) shows that soil $\mathrm{pH}$ and $\mathrm{EC}$ were significantly affected by integrated application of $S$ and $B$. Results clearly indicated that combined addition of biochar and sulphur (T4) led to decrease of soil pH by $2.98,3.89$ and $2.50 \%$ after harvest of wheat, 5.31, 5.53 and $3.73 \%$ after harvest soybean whereas EC decreased by $23.70,21.63$ and $21.54 \%$ after harvest wheat $31.09,33.59$ and $34.98 \%$ as compared to control for sandy, calcareous and clay soils, respectively.

Reduction of soil $\mathrm{pH}$ at the end of experiments might be due to release of protons $\left(\mathrm{H}^{+}\right)$from the exchange sites of biochar (B) and due to the spread of acid that produces soil microorganisms.The production of organic acid during the decomposition of OM present in soil and biochar may have contributed to a decrease in the $\mathrm{pH}$ of the soil. Shenbagavalli and Mahimairaja (2012) reported that biochar application at rates $1,2,3,4$ and $5 \%$ decreased soil $\mathrm{pH}$ in sandy clay loam soil by increasing periods 30, 60 and 90 day after application. Amini (2015) found that application amendments of biochar at 5 and $10 \% \mathrm{w} / \mathrm{w}$ and gypsum at rate $2 \% \mathrm{w} / \mathrm{w}$ reduction the values $\mathrm{pH}$ and $\mathrm{EC}$ in saline clay soil. Decline in soil $\mathrm{pH}$ and EC values due to chemical and biological reactions of each manure applied increase $\mathrm{CO}_{2}$ concentrations Which can reduce $\mathrm{pH}$ toward a neutral point and release $\mathrm{H}^{+}$when dissolved in water, the released $\mathrm{H}^{+}$enhances $\mathrm{CaCO}_{3}$ dissolution 
B. A. El-Gamal, et al.,

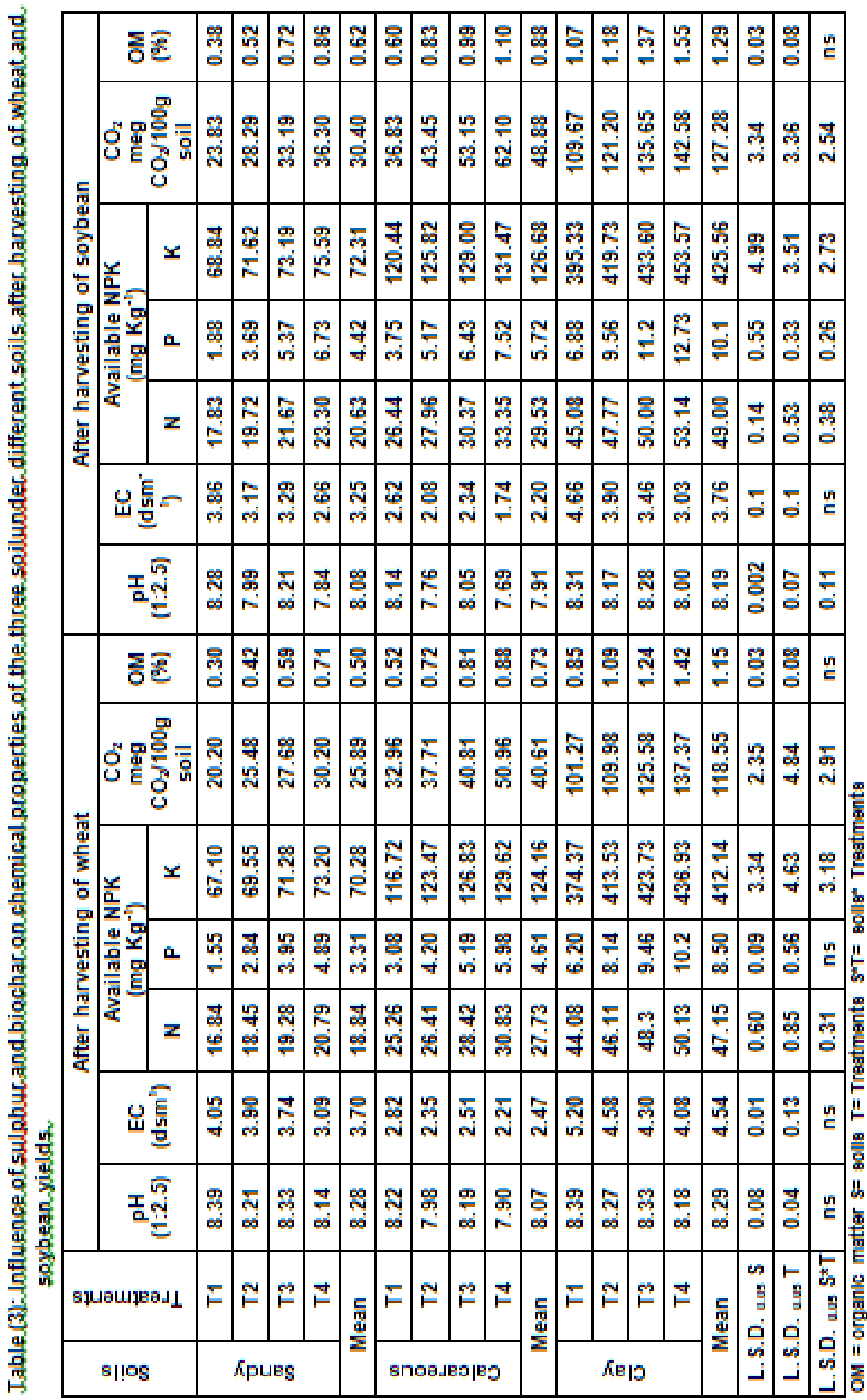


sodium exchange.These findings are in general agreement with the findings of Hasheminajd et al., (2012) and El-Gamal, (2015). Liu and Zhang (2012) found that biochar decrease the value soil $\mathrm{pH}$ in different alkaline soils. Mutowal et al., (2013) and Motior et al., (2011) found that

the use of sulphur at rates of $0.00,1.00$, 5.00 and $10.00 \mathrm{t} \mathrm{ha}^{-1}$ reduced soil $\mathrm{pH}$ and EC. The plots sulphur treated reduce soil $\mathrm{pH}(7.5,7.4$ and 7.4 respectively) as compared to control as shown by (Jamal et al., 2010).

\section{b- Available nutrients, organic matter and $\mathrm{CO}_{2}$ evolved in soils}

The results shown in Table (3) appeared positive responses of $\mathrm{N}, \mathrm{P}, \mathrm{K}$ available, organic matter and $\mathrm{CO}_{2}$ evolved with combined application of sulphur and biochar as compared to control treatments. The superior increases of nutrients availability were found with the treatments of biochar + sulphur, where the percent increases of these data nutrients in sandy soil 23.45 , $215.48,9.09,136.67$ and $49.50 \%$ and, were $22.05,94.16,11.05,69.23,54.61 \%$ in calcareous soil, where there were 13.73 , $64.52,16.71,67.06$ and $35.65 \%$ in clay soil for the content of available $\mathrm{N}, \mathrm{P}, \mathrm{K}$, organic matter and $\mathrm{CO}_{2}$ evolved respectively, as compared to control treatment after harvest wheat. Combined application sulphur and biochar give the greatest values of $\mathrm{N}, \mathrm{P}, \mathrm{K}$ available, organic matter and $\mathrm{CO}_{2}$ evolved were increase percent by $30.68,257.98,9.80$, 126.31 and $52.33 \%$ in sandy soil, were $26.10,100.53,9.16,83.33$ and $68.61 \%$ in calcareous soil, and were $17.88,85.03$, $14.73,44.86$ and $30.01 \%$ in clay soil with soil sample taken in harvest soybean $\mathbf{N}$, $\mathrm{P}, \mathrm{K}$ available, organic matter and $\mathrm{CO}_{2}$ evolved, respectively, as compared to untreatment. These results attributed to application of sulphur and biochar which led to improve nutrients status in soils may be due to biochar and sulphur were major source of nutrients through internal soil transformations. Nutrients are released and retained through six processes, immobilization, mineralization, precipitation dissolution, desorption and adsorption. Application of biochar often increases soil $\mathbf{N}$ availability because of improved nutrient retention increase evolution of $\mathrm{CO}_{2}-\mathrm{C}$. Organic $C$ is utilized for energy by decomposer microorganisms, its fate is to be assimilated into their tissues, released as metabolic products, or respired as carbon dioxide $\left(\mathrm{CO}_{2}\right)$. Energy organic $\mathrm{C}$ is used by decomposed microorganisms, their fate is absorbed into their tissues, released as metabolites, or exceeded as $\mathrm{CO}_{2}$. In this respect, similar results were obtained by Major et al., (2010a) and Prapagar et al., (2012). Application of sulphue and biochar resulted in a clear change soil physical, biological and chemical properties (Buchkina et al., 2019). Therefore, B application is a promising alternative to sequestration of more carbon compared to more traditional agricultural practices involving direct integration of biomass, (Bruun et al., 2011). This results in immediate and rapid mineralization, and the release of carbon dioxide. Moreover, soil chemical properties, including $\mathrm{OC}$ and nutrients availability were markedly affected by biochar (B). Availability of N, P and K were markedly increased in biochar treatments as compared with untreatment (Ali, 2018).

Nabavinia et al., (2015) found that application $B$ at rate $2.5 \mathrm{t} \mathrm{ha}^{-1}$ increased total soil nitrogen, available $P$ and $K$ as compared to without treatment in loamy sand soil. The application of sulfur at rates $200,300,400$ and $600 \mathrm{~kg}$ powdered $\mathrm{S} / \mathrm{fed}$, that is oxidized to $\mathrm{SO}_{4}^{-2}$ by soil microorganisms, expectedly lively lowers the $\mathrm{pH}$ value, and consequently increases the nutrients availability. 
Deekshitha et al., (2017) indicated that application of sulphur in clay loam soil led to increased $O M$ and available of NPK, while soil pH was decrease can be attributed to high availability of nutrients under decrease soil $\mathrm{pH}$ associated with use Sulphur application. The benefits that soybean can gain from organic amendments and Sulphur application may be related to the bioavailability of the substrate $C$ as well as release of nutrients, however may not be obtained in terms of stabilizing $\mathrm{N}_{2}$ in high-fertility soils.Also, the addition of biochar in clay loam plantation soil can increase the growth and yields of soybean, available $\mathrm{P}, \mathrm{K}$ and OM (Yooyen et al., 2015).

\section{c-Cation exchange capacity (CEC), exchangeable cations and exchangeable sodium percentage (ESP)}

Data in Table (4) shows the impact of $B$ and $S$ application individually and in together on CEC, ESP and exchangeable cations ( $\mathrm{Ca}, \mathrm{Mg}, \mathrm{Na}$ and $\mathrm{K})$. Results revealed that CEC and ESP values significant influence as a results of the used soil amendments applications. The greatest values of $\mathrm{CEC}, \mathrm{Ca}, \mathrm{Mg}$ and $\mathrm{K}$ after harvest of wheat with combined application of biochar and sulphur, which increased by $16.26,45.45,24.28$ and $42.86 \%$ in sandy soil, increased by 7.96 , $14.87,16.56$ and $66.67 \%$ in calcareous soil and increased by $9.51,34.66,14.38$ and $52.03 \%$ in clay soil respectively comparing with control treatment. Conversely, the values of exchangeable $\mathrm{Na}$ and ESP were decreased with biochar and sulphur application. However, biochar + sulphur mixture application led to decrease exchangeable $\mathrm{Na}$ and ESP by 26.47 and $36.43 \%$ in sandy soil, decreased by 20.52 and $26.45 \%$ in calcareous soil and decreased by 18.56 and $25.63 \%$ in clay soil comparing with the control, respectively. Where the values of $\mathrm{CEC}, \mathrm{Ca}, \mathrm{Mg}$ and $\mathrm{K}$ after harvest soybean increased by $22.12,57.95,37.20$ and $39.34 \%$ in sandy soil , $10.01,24.61$, 28.60 and $64.94 \%$ in calcareous soil and $9.02,42.35,18.01$ and $47.10 \%$ in clay soil with the treatment of sulphur + biohar mixture, receptivity comparing with without application. On the other side, exchangeable $\mathrm{Na}$ and ESP slightly decrease by biochar, sulphur and sulphur + biohar mixture applied. Actually, it can be observed that, the decrease rate of exchangeable $\mathrm{Na}^{+}$and ESP were 33.33 and $45.12 \%$ in sandy soil, 44.50 and $49.60 \%$ in calcareous soil and decreased by 34.08 and $39.50 \%$ in clay soil which recorded with the treatment of sulphur + biohar mixture application less than those in the control treatment, respectively. Also, the increasing in soil CEC was due to organic manure addition and the increasing in the amount of active groups of biochar and sulphur. (Wakode et al., 2011 and Dume et al., 2016).

Due to the oxidation of sulphur biologically by sulphur oxidizing bacteria and the production of sulfuric acid, which is the source of hydrogen ions. Sulphuric acid leads to the dissolve of both of calcium and magnesium, which is substituting exchangeable sodium, thereby leads to lowering soil ESP. These results are parallel with those obtained by El-Maddah et al., (2012). The use of biochar at rates $(3.00,6.00$ and $9.00 \mathrm{Mg}$ $\mathrm{ha}^{-1}$ ) provides increases in elements calcium and magnesium and effective CEC of the soil after a soybean cropping (Dos Passos et al., 2015). Kizito et al., (2019) showed that biochar application at rates 0.5 and $1.50 \%$ to clay loam soil led to increased CEC and availability $N, P$, $\mathrm{Ca}, \mathrm{Mg}$ and $\mathrm{K}$. FAO (2014) showed that sulphur applied in calcareous soils where the oxidation of elemental sulphur by microorganism to $\mathrm{H}_{2} \mathrm{SO}_{4}$ and solubilizing $\mathrm{CaCO}_{3}$ or forming $\mathrm{CaSO}_{4}$ to supply the calcium ions which replace the adsorbed 


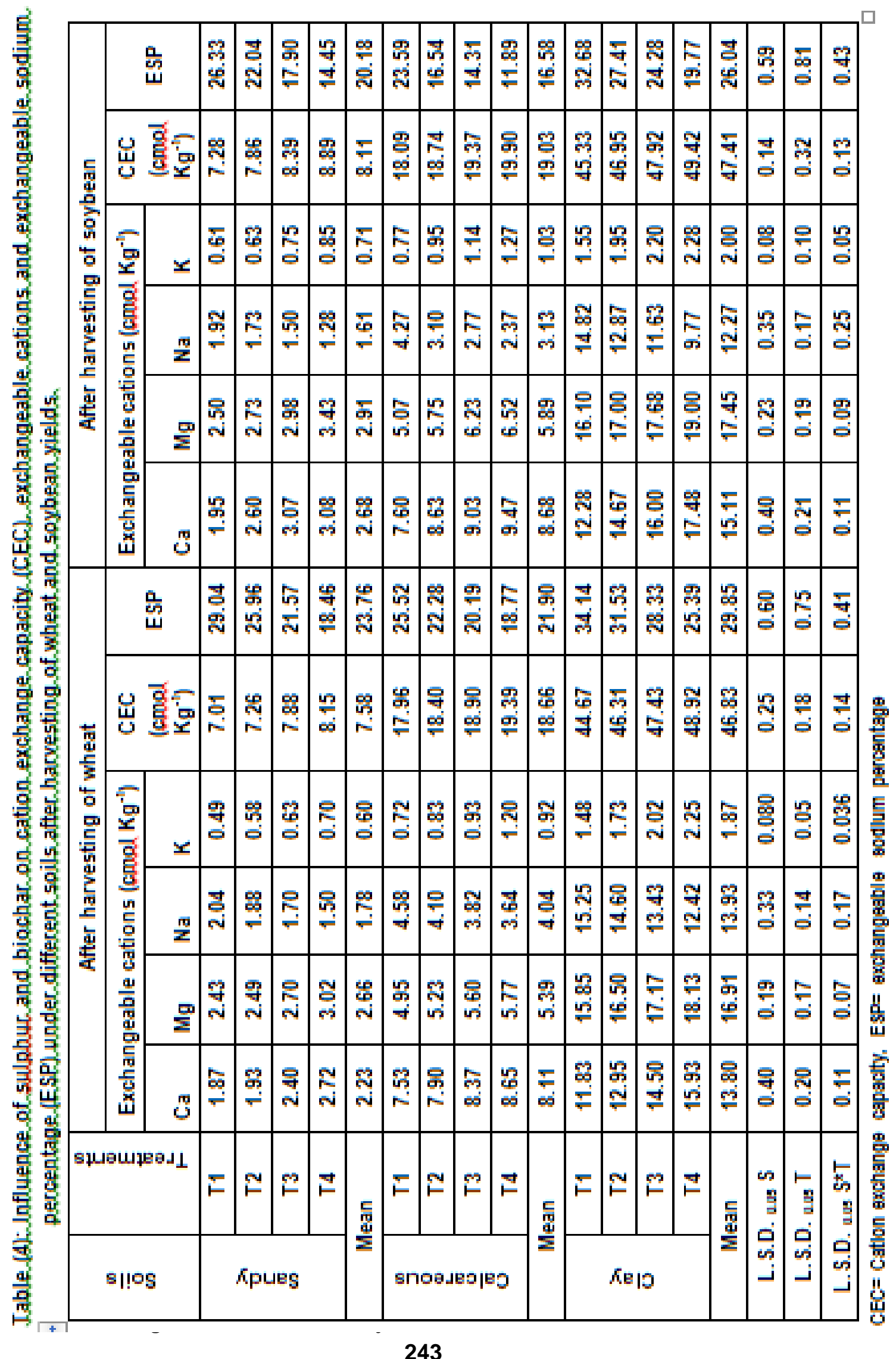


(2012) found that, application biochar at rates $1,2,3,4$ and $5 \%$ increased soil CEC and $O M$ in sandy clay loam soil by increasing periods 30,60 and 90 days after application. In addition, slowing oxidation of the biochar increased the number of carboxylic groups, which in turn increased the CEC in soil. Abrishamkesh et al., (2015) indicated that biochar application at rates $0.4,0.8,1.6$,

2.4 , and $3.3 \%$ by weight to clay loam soil significantly increased soil OC, CEC and available K. The biochar (B) application improved soil fertility status, especially soil O.C., CEC, available $P$, exchangeable $\mathrm{Ca}, \mathrm{Mg}$ and $\mathrm{K}$ in sandy loam soils. (Sukartono et al., 2011). The increment of soil CEC as a result of biochar application caused by this discretion can be seen by analyzing of $B$, such as high porosity and surface area. High $\mathrm{OC}$ and CEC in soils amended by biochar. (Nigussie et al., 2012).

\section{Effects of sulphur and biochar applied on soil physical properties}

Moreover, the influence of sulphur and biochar application individually and in combination on bulk density (Bd), total porosity (Tp) and hydraulic conductivity $(\mathrm{Hc})$ in different soils were presented in Table (5). All treatments of Sulphur and biochar application significantly effect on $\mathrm{Bd}, \mathrm{Tp}$ and $(\mathrm{Hc})$ after harvest of wheat and soybean. The mean values of bulk density after harvest of wheat in sandy soil were decreased from1.60 to (1.57, 1.51 and $1.47 \mathrm{~g} \mathrm{~cm}^{-3}$ ), from 1.45 to $(1.42$, 1.38 and $1.34 \mathrm{~g} \mathrm{~cm}^{-3}$ ) in calcareous soil and from 1.22 to $(1.18,1.15$ and $1.11 \mathrm{~g}$ $\mathrm{cm}^{-3}$ ) in clay soil, as compared with control of sulphur, biochar and sulphur+ biochar mixture application, respectively. On the other hand, the values of total porosity differed significant and increase from 39.62 to $(40.75,43.02$ and $44.53 \%)$ in sandy soil and from 45.28 to $(46.42,47.92$ and
$49.43 \%$ ) in calcareous soil, and from 53.96 to $(55.47,56.60$ and $58.11 \%)$ in clay soil, as compared with control of sulphur, biochar and sulphur+ biochar mixture application, respectively. The values of hydraulic conductivity were decreased from 18.09 to $(16.83,14.85$ and $13.67 \mathrm{~cm}$ $\mathrm{h}^{-1}$ ) in sandy soil, decreased by 9.09 to $\left(7.26,7.76\right.$ and $\left.7.25 \mathrm{~cm} \mathrm{~h}^{-1}\right)$ in calcareous soil and increased from 0.78 to $(1.07,1.36$ and $1.70 \mathrm{~cm} \mathrm{~h}^{-1}$ ) in clay soil, as compared with control of sulphur, biochar and sulphur+ biochar mixture application, respectively. On the other hand, it is clear from the data that, the mean values of bulk density after harvest soybean decreased from 1.58 to $(1.53,1.48$ and $1.44 \mathrm{~g} \mathrm{~cm}^{-3}$ ) in sandy soil, decreased from 1.43 to $\left(1.41,1.34\right.$ and $\left.1.31 \mathrm{~g} \mathrm{~cm}^{-3}\right)$ in calcareous soil and decreased from 1.22 to $\left(1.18,1.15\right.$ and $\left.1.11 \mathrm{~g} \mathrm{~cm}^{-3}\right)$ in clay soil, as compared with control of sulphur, biochar and sulphur+ biochar mixture application, respectively. On the contrary, total porosity values in soils increase significant and reached to $\mathbf{4 0 . 3 8}$ to ( $42.26,44.15$ and $45.66 \%$ ) in sandy soil, increase from 46.04 to $(46.79,49.43$ and $50.57 \%$ ) in calcareous soil, and increase from 54.34 to $(56.23,58.11$ and $60.38 \%$ ) in clay soil, as compared with control of sulphur, biochar and sulphur+ biochar mixture application, respectively. The values of hydraulic conductivity were significant influence due application of sulphur, biochar and sulphur+ biochar mixture when compared with control treatments. However, the response of hydraulic conductivity is comparatively observed with sulphur and biochar rates than that obtained under control treatment. The values decrease from 17.16 to (15.25, 13.36 and $11.29 \mathrm{~cm} \mathrm{~h}^{-1}$ ) in sandy soil, decrease from 8.17 to $(7.78,7.15$ and 6.08 $\mathrm{cm} \mathrm{h^{-1 }}$ ), while in clay soil, the values increase from 0.96 to $(1.43,2.10$ and 2.86 $\mathrm{cm} \mathrm{\textrm {h } ^ { - 1 }}$ ) as compared with control of 
sulphur, biochar and sulphur+ biochar mixture application, respectively.

These results may be due to that stay long time of sulphur stimulate the microbial oxidation and led to the aggregating effect on soil particles, which create more aggregates leading to increase the apparent volume, consequently, then decrease bulk density. This increase of Tp may be due to that organic matter lead to synthesis of compound that bind soil particles and produced stable aggregates. physical properties would be improved, wherever, these aggregates help maintain a loose, open, and open state water, the more it can infiltrate and infiltrate the soil, requires constant supplies of $\mathrm{CO}_{2}$ to enable it to encroach and grow, and greater poverty allows for better exchange of gases between soil and the atmosphere. These findings are consistent with the reported by ElSodany et al., (2012) and Hashemimajd et al., (2012). Application of biochar significantly decreases $\mathrm{Hc}$ and $\mathrm{Bd}$. It was also noted that, the increase biochar led to a significant reduction in the waterrepellent soil. An increase in water retention was also observed at low matrix potential, where increased biochar were found to be able to hold more water when the soil was dry.(Verheijen et al., (2010) and Barnes et al., 2014). Ali, (2018) showed that incorporation of biochar at rates $0,4.20,8.40$ and $16.80 \mathrm{~g} \mathrm{~kg}^{-1}$ caused significant improvements in the physical properties of the soil through decreasing $\mathrm{Bd}$ and increasing Td, water-holding capacity and volumetric water. Biochar is expected to increase the drainage of sandy soil slowly. (Atkinson et al., 2010) and clay-rich soils to drain water more quickly (Major et al., 2010b). However, the above results have not been consistent, and are likely to be the result of confounding factors such as biochar properties (e.g. raw materials, heatprojection temperatures), application rates, and soil characteristics.

Table (5): Influence of sulphur and biochar on some physical properties under different soils after harvesting of wheat and soybean yields.

\begin{tabular}{|c|c|c|c|c|c|c|c|}
\hline \multirow{2}{*}{ क्ष } & \multirow{2}{*}{ 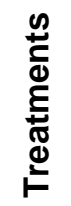 } & \multicolumn{3}{|c|}{ After harvesting of wheat } & \multicolumn{3}{|c|}{ After harvesting of soybean } \\
\hline & & $\begin{array}{c}\mathrm{Bd} \\
\left(\mathrm{g} \mathrm{cm}^{-1}\right)\end{array}$ & Tp (\%) & $\begin{array}{c}\text { Hc } \\
\left(\mathrm{Cm} \mathrm{hr}^{-1}\right)\end{array}$ & $\mathrm{Bd}_{\left.\mathrm{cm}^{-1}\right)}(\mathrm{g}$ & TP (\%) & $\begin{array}{c}\mathrm{HC} \\
\left(\mathrm{Cm} \mathrm{hr}^{-1}\right) \\
\end{array}$ \\
\hline \multirow{4}{*}{ 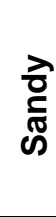 } & T1 & 1.60 & 39.62 & 18.09 & 1.58 & 40.38 & 17.16 \\
\hline & T2 & 1.57 & 40.75 & 16.83 & 1.53 & 42.26 & 15.25 \\
\hline & T3 & 1.51 & 43.02 & 14.85 & 1.48 & 44.15 & 13.36 \\
\hline & T4 & 1.47 & 44.53 & 13.67 & 1.44 & 45.66 & 11.29 \\
\hline \multicolumn{2}{|c|}{ Mean } & 1.54 & 41.98 & 15.86 & 1.51 & 43.11 & 14.27 \\
\hline \multirow{4}{*}{ 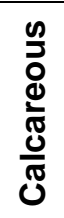 } & T1 & 1.45 & 45.28 & 9.09 & 1.43 & 46.04 & 8.17 \\
\hline & T2 & 1.42 & 46.42 & 7.26 & 1.41 & 46.79 & 7.78 \\
\hline & T3 & 1.38 & 47.92 & 7.79 & 1.34 & 49.43 & 7.15 \\
\hline & T4 & 1.34 & 49.43 & 7.25 & 1.31 & 50.57 & 6.08 \\
\hline \multicolumn{2}{|c|}{ Mean } & 1.40 & 47.26 & 7.85 & 1.37 & 48.21 & 7.29 \\
\hline \multirow{3}{*}{$\frac{\vec{\pi}}{0}$} & T1 & 1.22 & 53.96 & 0.78 & 1.21 & 54.34 & 0.96 \\
\hline & T2 & 1.18 & 55.47 & 1.07 & 1.16 & 56.23 & 1.43 \\
\hline & T3 & 1.15 & 56.60 & 1.36 & 1.11 & 58.11 & 2.10 \\
\hline
\end{tabular}


B. A. El-Gamal, et al.,

\begin{tabular}{|c|c|c|c|c|c|c|}
\hline T4 & 1.11 & 58.11 & 1.70 & 1.05 & 60.38 & 2.86 \\
\hline Mean & 1.17 & 56.04 & 1.23 & 1.32 & 57.26 & 1.84 \\
\hline L.S.D. 0.05 S & 0.02 & 0.85 & 0.34 & 0.01 & 0.39 & 0.33 \\
\hline L.S.D. 0.05 T & 0.02 & 0.71 & 0.43 & 0.02 & 0.69 & 0.49 \\
\hline L.S.D. $0.05 \mathbf{S}^{\star} \mathbf{T}$ & ns & ns & 0.31 & ns & ns & 0.57 \\
\hline
\end{tabular}

$\mathrm{Bd}=$ bulk density, $\mathrm{Tp}=$ Total porosity and $\mathrm{Hc}=$ hydraulic conductivity

III. Effect of sulphur and biochar on wheat and soybean plants

a- Grain and straw yields of wheat and soybean

Grain and straw yields of both crops grown on three soils were affected significantly by the application sulphur and biochar individually and together as shown as in Tables (6 and 7). Where these application resulted in a significantly increase grain and straw of the plants. The highest yields of grains and straw were found with combined application sulphur and biochar. In addition, there demonstrating the beneficial impact of $S$ and $B$ on wheat and soybean yields. The substantially, analysis showed that adding sulphur + biochar mixture gave the highest values in wheat grain and straw.

Table (6): Influence of sulphur and biochar on wheat grain, straw yield ( $\mathrm{Mg} \mathrm{ha}^{-1}$ ) and nutrients concentration (\%) under different soils.

\begin{tabular}{|c|c|c|c|c|c|c|c|c|c|}
\hline \multirow{2}{*}{ 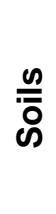 } & \multirow{2}{*}{ 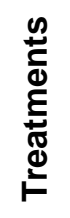 } & \multirow{2}{*}{$\begin{array}{c}\text { Gain } \\
\text { yield } \\
\left(\mathrm{Mg} \mathrm{ha}^{-1}\right)\end{array}$} & \multirow{2}{*}{$\begin{array}{c}\text { Straw } \\
\text { yield } \\
\left(\text { Mg ha }^{-1}\right)\end{array}$} & \multicolumn{3}{|c|}{$\begin{array}{c}\text { NPK concentration in } \\
\text { grain (\%) }\end{array}$} & \multicolumn{3}{|c|}{$\begin{array}{l}\text { NPK concentration in } \\
\text { straw (\%) }\end{array}$} \\
\hline & & & & $\mathbf{N}$ & $\mathbf{P}$ & $K$ & $\mathbf{N}$ & $\mathbf{P}$ & $K$ \\
\hline \multirow{4}{*}{$\begin{array}{l}\frac{2}{0} \\
\frac{\Gamma}{\pi} \\
\text { ஸे }\end{array}$} & $\mathrm{T} 1$ & 4.52 & 5.86 & 1.78 & 0.12 & 0.39 & 0.60 & 0.06 & 1.51 \\
\hline & T2 & 4.71 & 6.08 & 1.82 & 0.16 & 0.52 & 0.68 & 0.07 & 1.58 \\
\hline & T3 & 4.82 & 6.40 & 1.86 & 0.19 & 0.58 & 0.75 & 0.08 & 1.68 \\
\hline & T4 & 5.10 & 6.77 & 1.92 & 0.21 & 0.67 & 0.78 & 0.09 & 1.77 \\
\hline \multicolumn{2}{|c|}{ Mean } & 4.79 & 6.28 & 1.85 & 0.17 & 0.54 & 0.70 & 0.08 & 1.64 \\
\hline \multirow{4}{*}{ 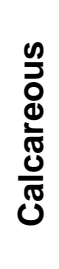 } & $\mathrm{T} 1$ & 4.95 & 7.03 & 1.88 & 0.14 & 0.48 & 0.68 & 0.07 & 1.58 \\
\hline & T2 & 5.57 & 7.91 & 1.98 & 0.17 & 0.72 & 0.77 & 0.08 & 1.72 \\
\hline & T3 & 5.27 & 7.51 & 2.10 & 0.19 & 0.77 & 0.82 & 0.10 & 1.78 \\
\hline & T4 & 6.18 & 7.78 & 2.17 & 0.22 & 0.82 & 0.93 & 0.11 & 1.87 \\
\hline \multicolumn{2}{|c|}{ Mean } & 5.49 & 7.56 & 2.03 & 0.18 & 0.70 & 0.80 & 0.09 & 1.74 \\
\hline \multirow{4}{*}{$\frac{\vec{\pi}}{0}$} & T1 & 6.32 & 7.71 & 1.95 & 0.18 & 0.55 & 0.82 & 0.08 & 1.75 \\
\hline & T2 & 6.77 & 8.38 & 2.10 & 0.21 & 0.73 & 0.88 & 0.11 & 1.87 \\
\hline & T3 & 7.17 & 9.06 & 2.26 & 0.24 & 0.82 & 1.02 & 0.15 & 2.00 \\
\hline & T4 & 7.77 & 9.44 & 2.51 & 0.27 & 0.92 & 1.2 & 0.17 & 2.17 \\
\hline
\end{tabular}


Impact of sulphur and biochar applications on soil properties and

\begin{tabular}{|c|c|c|c|c|c|c|c|c|}
\hline \multicolumn{1}{|c|}{ Mean } & 7.01 & 8.65 & 2.21 & 0.23 & 0.76 & 0.98 & 0.13 & 1.95 \\
\hline L.S.D. 0.05 S & 0.10 & 0.41 & 0.055 & 0.02 & 0.06 & 0.062 & 0.020 & 0.02 \\
\hline L.S.D. 0.05 T & 0.16 & 0.27 & 0.072 & 0.02 & 0.066 & 0.057 & 0.08 & 0.04 \\
\hline L.S.D. 0.05 S T & 0.040 & ns & 0.067 & ns & ns & ns & 0.033 & ns \\
\hline
\end{tabular}

Table (7): Influence of sulphur and biochar on soybean grain, straw yield ( $\left.\mathrm{Mg} \mathrm{ha}^{-1}\right)$ and nutrients concentration (\%) under different soils.

\begin{tabular}{|c|c|c|c|c|c|c|c|c|c|}
\hline \multirow{2}{*}{ 我 } & \multirow{2}{*}{ 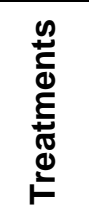 } & \multirow{2}{*}{$\begin{array}{c}\text { Gain } \\
\text { yield } \\
\left(\text { Mg ha }^{-1}\right)\end{array}$} & \multirow{2}{*}{$\begin{array}{c}\text { Straw } \\
\text { yield } \\
\left(\mathrm{Mg} \mathrm{ha}^{-1}\right)\end{array}$} & \multicolumn{3}{|c|}{$\begin{array}{l}\text { NPK concentration in } \\
\text { grain }(\%)\end{array}$} & \multicolumn{3}{|c|}{$\begin{array}{l}\text { NPK concentration in } \\
\text { straw }(\%)\end{array}$} \\
\hline & & & & $\mathbf{N}$ & $\mathbf{P}$ & $K$ & $\mathbf{N}$ & $\mathbf{P}$ & $\mathrm{K}$ \\
\hline \multirow{4}{*}{$\begin{array}{l}\frac{7}{0} \\
\frac{2}{\pi} \\
\text { cे }\end{array}$} & T1 & 1.22 & 1.79 & 3.81 & 0.25 & 0.67 & 1.70 & 0.15 & 1.67 \\
\hline & T2 & 1.55 & 1.99 & 4.01 & 0.29 & 0.82 & 1.85 & 0.19 & 1.73 \\
\hline & T3 & 1.83 & 2.63 & 4.27 & 0.32 & 1.02 & 2.06 & 0.22 & 1.87 \\
\hline & T4 & 2.11 & 2.90 & 4.75 & 0.37 & 1.15 & 2.23 & 0.26 & 2.00 \\
\hline \multicolumn{2}{|c|}{ Mean } & 1.68 & 2.33 & 4.21 & 0.31 & 0.92 & 1.96 & 0.21 & 1.82 \\
\hline \multirow{4}{*}{ 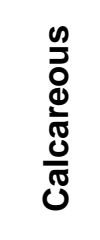 } & T1 & 1.38 & 2.08 & 4.28 & 0.28 & 0.82 & 1.83 & 0.20 & 1.75 \\
\hline & T2 & 2.06 & 2.61 & 4.62 & 0.34 & 1.15 & 1.95 & 0.26 & 1.88 \\
\hline & T3 & 1.86 & 2.45 & 5.12 & 0.32 & 1.19 & 2.12 & 0.25 & 2.09 \\
\hline & T4 & 2.43 & 3.04 & 5.50 & 0.40 & 1.23 & 2.33 & 0.30 & 2.23 \\
\hline \multicolumn{2}{|c|}{ Mean } & 1.93 & 2.55 & 4.88 & 0.34 & 1.10 & 2.06 & 0.25 & 1.99 \\
\hline \multirow{4}{*}{$\frac{\pi}{0}$} & T1 & 1.77 & 2.44 & 5.06 & 0.32 & 1.02 & 2.08 & 0.22 & 1.80 \\
\hline & T2 & 1.96 & 2.78 & 5.35 & 0.35 & 1.17 & 2.33 & 0.28 & 2.02 \\
\hline & T3 & 2.61 & 3.32 & 5.72 & 0.41 & 1.28 & 2.39 & 0.32 & 2.28 \\
\hline & T4 & 3.12 & 4.13 & 6.15 & 0.46 & 1.37 & 2.51 & 0.34 & 2.43 \\
\hline \multicolumn{2}{|c|}{ Mean } & 2.37 & 3.17 & 5.57 & 0.39 & 1.21 & 2.33 & 0.29 & 2.13 \\
\hline \multicolumn{2}{|c|}{ L.S.D. ${ }_{0.05} \mathrm{~S}$} & 0.086 & 0.012 & 0.096 & 0.01 & 0.043 & 0.072 & 0.018 & 0.082 \\
\hline \multicolumn{2}{|c|}{ L.S.D. ${ }_{0.05} \mathrm{~T}$} & 0.077 & 0.14 & 0.18 & 0.02 & 0.052 & 0.061 & 0.022 & 0.066 \\
\hline \multicolumn{2}{|c|}{ L.S.D. ${ }_{0.05} S^{\star} T$} & 0.023 & 0.17 & ns & ns & 0.036 & ns & 0.012 & 0.038 \\
\hline
\end{tabular}

This increase recorded 12.83 and $15.53 \%$ in sandy soil, 24.85 and $10.67 \%$ in calcareous soil and 22.94 and $22.44 \%$ in clay soil as compared control, respectively (Table 6). The percent of increase in soybean grain and straw yield were 72.95 and $62.01 \%$ in sandy soil, 76.09 and $46.15 \%$ in calcareous soil, and 76.27 and $69.26 \%$ in clay soil (Table 7 ) due to combined application of sulphur and biochar than the without treatment, respectively. The synergistic effect of sulfur may be attributed to the use of high amounts of nutrients through its advanced root system and nodules that may have resulted in better growth and better soil yield. The influence of biochar on seeds dry weight of soybean is due to 
its properties. This is because biochar is so well preserved with nutrients and increased, reduce loss of nutrient caused by erosion, improve water absorption, relieve soil density and enhance the growth of beneficial microorganisms. A study undertaken by Agboola and Moses (2015) found that the yield of soybean increased due to addition of rice husk biochar. Similarly, soil characteristics such as soil $\mathrm{pH}$ and the content of $(\mathrm{N}, \mathrm{Ca}$, $\mathrm{Mg}, \mathrm{K}$ and $\mathrm{Na}$ ) change due to the use of biochar in soil. Gebremedhin et al., (2015). Ali (2018) revealed that B amended soils at rate $4 \mathrm{Mg} \mathrm{ha}^{-1}$ of Tigray region, north Ethiopia increases significantly yield of wheat. Thus, the presence of plant nutrients and charcoal in the biochar could have increased the production of wheat in $B$ treatment soils. Applying B properties is therefore formal in order to increase soil fertility, water retention, and wheat productivity. Biochar enriched with sulfur, produced by exposure to $\mathrm{H}_{2} \mathrm{~S}$ generated from landfill biogas, can be used as a beneficial agricultural $S$ fertilizer for promoting corn and soybean plant growth (Zhang et al., 2017). Erdem et al., (2016) found that sulphur application at rates $0.00,25.00,50.00$ and $100.00 \mathrm{mg} \mathrm{S}$ $\mathrm{kg}^{-1}$ led to increased wheat yield most depend on soil characteristics, especially available sulfur levels in Eskisehir and Konya soils. Sulphur fertilization increased crop yields by $16.00 \%$ to $31.00 \%$ of crops studied in Brazil's NT soils.

Pias et al., (2019) and Zhu et al., (2018) showed that application biochar at rates $0,0.15,0.75$ and $1.5 \%, w / v$ improve soybean seedling growth in sandy soil. The modification of biochar has resulted in a statistically significant increase in the root Shoot dry weight from soybeans. (Egamberdieva et al., 2016). Suppadit et al., (2012) showed that biochar application at rates of $0,24.60,49.20$, $73.80,98.40$ and $123.00 \mathrm{~g}$ per pot a mixture has been served to soybean. Increased sulphur application led to a significant increase in soybean protein content. The positive response to additional sulphur is assigned to the low soil position available or because of the catalytic effect of sulphur used in the creation of chloroplast protein, which in turn increases the efficiency of photosynthesis, which translates into an increase in yield (Suman et al., 2018). Additionally, Gebremedhin et al., (2015) sohowed that biochar application significantly increased wheat grain and straw yields by 15.7 and $16.5 \%$, respectively, over the NPK application alone. Gupta et al., (2019) showed that biochar at rate $5 \mathrm{Mg} \mathrm{ha}^{-1}$ in sandy loam soil significantly increased wheat yield, $P$ and $K$ concentration as compared to control. Gondek and Kopeć (2010) found that application sulphur at rates 0.04 and $0.14 \mathrm{~g} \mathrm{~S} \mathrm{~kg}$ soil led to increased wheat grain and straw yield. S-application at the levels 400 and $600 \mathrm{~kg}$ powdered S/fed in calcareous soil caused significant or highly significant increases in plant growth and $\mathbf{N}$ and $\mathbf{P}$ uptakes as well as in yield and yield components compared with zero $S$ or the treatment supplied with $200 \mathrm{~kg} \mathrm{~S} / \mathrm{fed}$. The application of $400 \mathrm{~kg} \mathrm{~S}$ and $600 \mathrm{~kg} \mathrm{~S} / \mathrm{fed}$ resulted in $11.5 \%$ and $\mathbf{1 7 . 8} \%$ increases in grain yield, and $\mathbf{1 2 . 5}$ and $21 \%$ in straw yield, respectively (Badawy et al., 2011).

b- $N, P$ and $K$ concentration and uptake of wheat and soybean grain and straw.

Data in Tables (6 and 7) and (Fig 1, 2 and 3) indicate that $N, P$ and $K$ concentrations in wheat and soybean grain and straw significantly increased by the application of all the experimental treatments. It is also clear that the values of such nutrients were higher under the adding sulphur + biochar mixture applications than the other 
treatments.The best treatment was increasing $N, P$ and $K$ by sulphur + biochar mixture applications., as the rate of increment over the control in wheat grains due to such treatment reached to $7.87,75.00$ and $71.79 \%$ in sandy soil, $15.43,57.14$ and $70.83 \%$ in calcareous soil and recorded 28.72, 50.00 and $67.27 \%$ in clay soil for $N, P$ and $K$ concentrations, respectively. The respective values for wheat straw were $30.00,50.00$ and $17.22 \%$ in sandy soil, $36.76,57.14$ and $18.35 \%$ in calcareous soil, and $46.34,112.50$ and $24.00 \%$ in clay soil. It is also clear that the values of such nutrients took the same trends previously mentioned for $N, P$ and $K$ concentrations in soybean grain and straw. The highest increases of $N, P$ and $K$ concentrations in soybean grain were found with the sulphur and biochar mixture application treatment, as the increases reached to $24.67,48.00$ and $71.64 \%$ in sandy soil, $28.50,42.86$ and $50.00 \%$ in calcareous soil and recorded $21.54,43.75$ and $34.31 \%$ in clay soil, respectively. The respective increases for $\mathbf{N}, \mathbf{P}$ and $\mathbf{K}$ concentrations in soybean straw were $31.18,73.33$ and $19.76 \%$ in sandy soil, 27.32, 50.00 and $27.43 \%$ in calcareous soil and 20.67, 54.55 and $35.00 \%$ in clay soil as compared with control. The application of sulphur and biochar mixture led to increase in NPK uptake $\left(\mathrm{kg} \mathrm{ha}^{-1}\right)$ by grain and straw of wheat and soybean for all the two seasons as compared with control treatment, where the percentage increases $N, P, K$ uptake of wheat grain values reached $21.70,97.60$ and $93.82 \%$ in sandy soil, $44.11,96.25$ and $113.30 \%$ in calcareous soil and 58.25, 84.36 and $105.64 \%$ in clay soil, as compared control, respectively. The respective $N, P$, $K$ uptake of wheat straw values under sulphur + biochar mixture application were $50.20,88.62$ and $35.42 \%$ in sandy soil, 51.36, 66.86 and $30.99 \%$ in calcareous soil, and $79.18,150.78$ and
$51.82 \%$ in clay soil over the control. The positive effect of such materials on increasing macro-nutrients concentrations in wheat and soybean may be attributed to that these materials serve as valuable soil amendments that provide a balanced pattern of release of nutrients to plants, and provide nutrients in a readily available form that plants can easily take (Ferreras et al., 2006). Furthermore, biochar have been reported to enhance mineral nutrient uptake by plants, because it affects the Permeability of root membranes. Sulphur + biochar added to the soil resulted in statistically significant increase in NPK uptake by grain and straw of wheat and soybean compared to the control treatment. Application of biochar on crop production may be determined by changes in soil properties and/or the nutrients availability. The data indicated the progressive increment in NPK uptake of wheat and soybean grain and straw by sulphur, biochar and sulphur + biochar mixture application rate and residual effect rate. The elemental uptake of nutrients within the different parts of soybean plants grown on the studied soils as affected by different amendments are also shown in Fig (1, 2 and 3). Results revealed that uptake nutrients were significantly higher under sulphur + biochar mixture application compared to control. Moreover, such concentrations were higher in plants grown on the clayey soils than corresponding ones obtained from plants grown on the calcareous and sandy soil. It was obvious from the results that the movement of macronutrients from roots to grains was, generally, higher in plants sulphur + biochar mixture application compared to control treatment. The percent increases in the uptake of $N, P$ and $K$ in grain soybean were 115.64, 156.06 and $197.06 \%$ in sandy soil, 126.29 , 151.81 and $164.04 \%$ in calcareous soil and $114.25,153.53$ and $136.79 \%$ in clay 
soil under sulphur + biochar mixture application as compared control.

Data in Fig (1, 2 and 3) declare a noticeable increasing in uptake of wheat as a result of sulphur + biochar mixture application as compared with without treatments during the two seasons, NPK uptake of soybean was high significantly increased in the combined treatments of sulphur + biochar mixture applied than those under their sole application and control, during the two growing seasons. Consequently the effect of treatments application on uptake can be arranged in the following order sulphur + biochar mixture $>$ biochar $>$ sulphur $>$ control. The percent increases in the uptake of $N$, $P$ and $K$ in grain soybean were 112.52 , 180.30 and $94.04 \%$ in sandy soil, 86.10 ,
119.23 and $86.24 \%$ in calcareous soil and $104.26,161.45$ and $128.51 \%$ in clay soil under sulphur + biochar mixture application as compared control. Also, NPK content and uptake of grain and straw of wheat and soybean could be placed according to its content in the following descending sequence: clay soil $>$ calcareous soil > sandy soil. This finding may be due to the higher indigenous fertility and CEC values of the clay soil compared to the corresponding ones of the calcareous soil and sandy soil. The reported changes produced by the application of elemental sulfur to sandy soil were decreased soil $\mathrm{pH}$ and increased wheat yield and macronutrients uptake (Badawy et al., 2011).

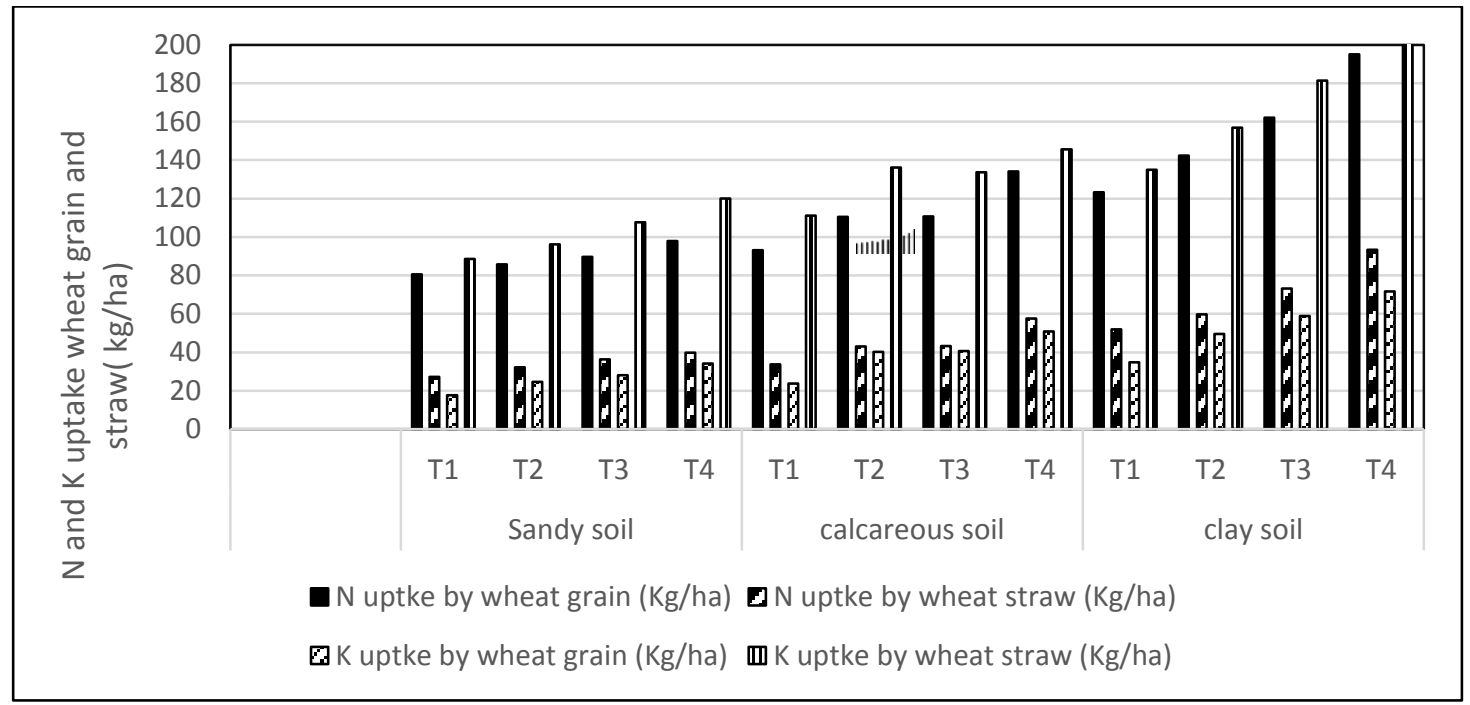

Figure (1): Impact of sulphur and biochar on $\mathrm{N}$ and $\mathrm{K}$ uptake of grain and straw of wheat under different soils 


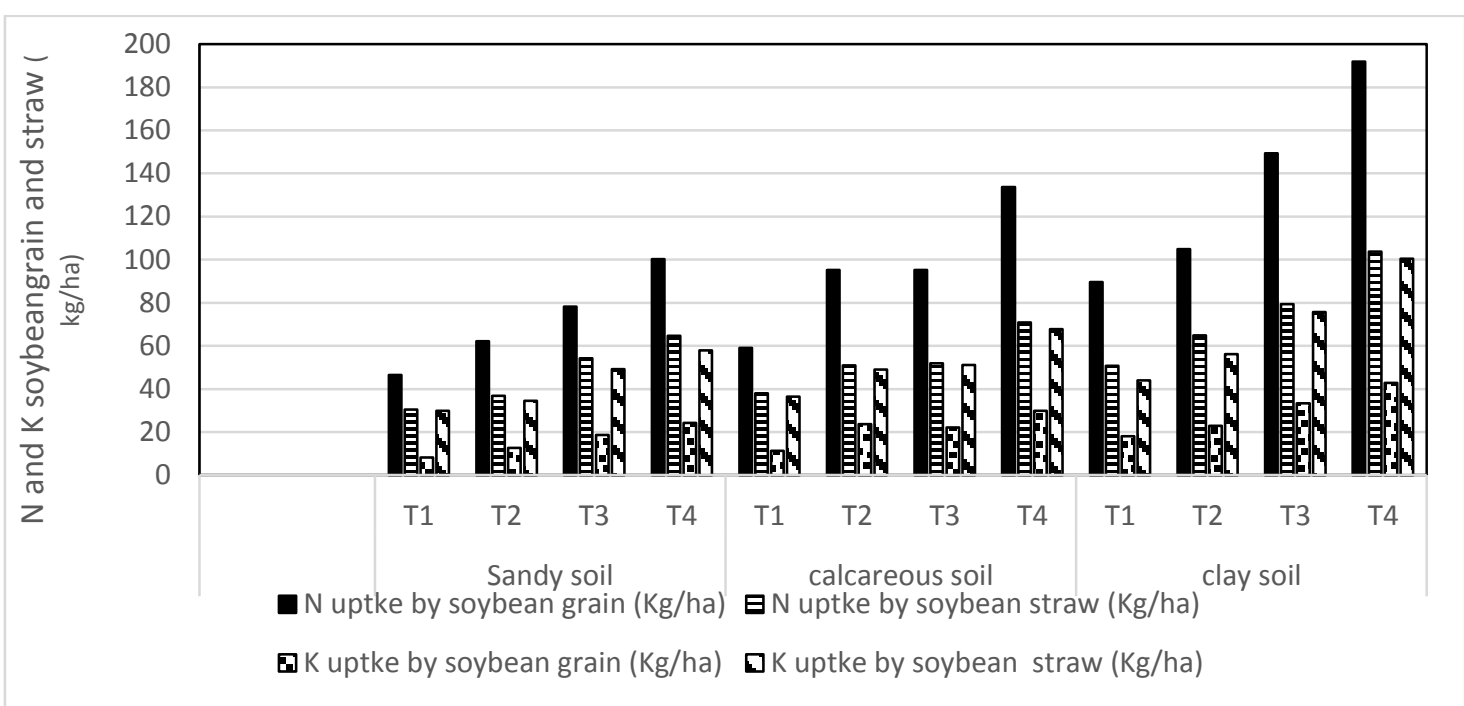

Figure (2): Impact of sulphur and biochar on $\mathrm{N}$ and $\mathrm{K}$ uptake of grain and straw of soybean under different soils

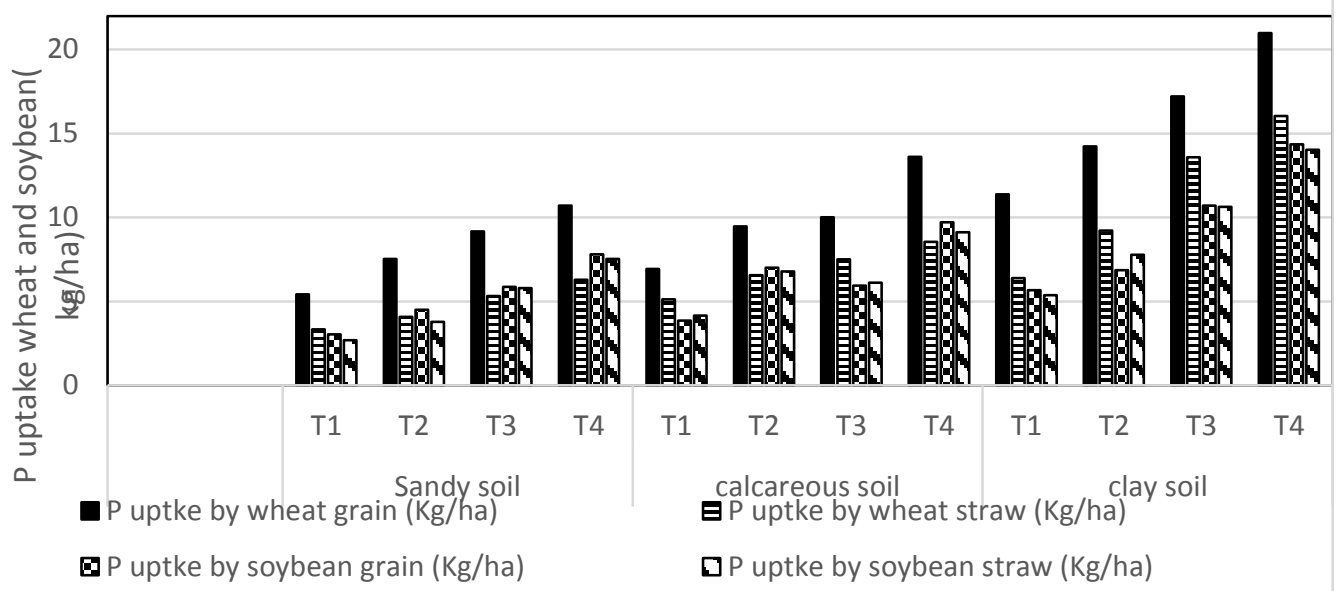

Figure (3): Impact of sulphur and biochar on P uptake of grain and straw of wheat and soybean under different soils.

Biochemical oxidation produces the sulphur dioxide $\mathrm{H}_{2} \mathrm{SO}_{4}$ that reduces soil $\mathrm{pH}$ and solubilizes calcium carbonate in calcareous soils conditions more suitable for plant growth, this is availability by plant nutrients (EI-Tarabily et al., 2006). Abdallah et al., (2010) and Dhage et al., (2014) Showed that the impact of different levels of sulphur on the crop, the concentration of plant nutrients, and uptake and availability of nutrients in the harvesting of soybeans.
In Egypt, a number of investigators reported the combined impact of applying sulphur $(200-500 \mathrm{~kg} / \mathrm{fed})$ or gypsum (2.67 ton/fed) with FYM in calcareous soils, on yields obtained as well as on concentrations and uptake of macronutrients. (Awad et. al., 2002). Wheat yield as affected by various sources and level of sulphur at rates of 0 , 20,40 and $60 \mathrm{mg} \mathrm{kg}^{-1}$ soil revealed that grain and straw yield and NPK concentrations and uptake significant increase with increasing level of sulphur 
than control in sandy soil. (Sharma and Sharma, 2014 and Sangwan et al., 2018).

\section{Conclusion}

It could be concluded that, Results of the current study indicated the beneficial application of sulphur (S) and biochar (B) alone or in combination can improve soil fertility, soil physical and chemical properties. Also, these applications caused high increases in availability of $\mathbf{N}$, $P$ and $K$ and high enhancements in exchangeable $\mathrm{Ca}, \mathrm{K}, \mathrm{Na}, \mathrm{Mg}$, CEC, ESP and organic carbon). Therefore, it is recommended that farmers can apply the studied amendments for increasing the productivity of wheat and soybean crops with good seed quality under Egypt soil different conditions.

\section{REFERENCES}

Abdallah, M., L. Dubousset, F. Meuriot, P. Etienn, J.C. Avice and A. Ourry (2010). Effect of mineral sulphur availability on nitrogen and sulphur uptake and remobilization during the vegetative growth of Brassica napus L. J Expt Bot 61(10): 2635-2646.

Abdou, A.S. (2006). Effect of applied elemental sulfur and sulfur-oxidizing bacteria (Parococcus versutus) into calcareous sandy soils on the availability of native and applied phosphorus and some micronutrients. In: $18^{\text {th }}$ World Congress of Soil Science, Philadelphia, Pennsylvania, USA. July 9-15.

Abrishamkesh, S., M. Gorji, H. Asadi, G.H. Bagheri-Marandi and A.A. Pourbabaee (2015). Effects of rice husk biochar application on the properties of alkaline soil and lentil growth. Plant Soil Environ., 61(11): 475-482.

Agboola, K. and S.A. Moses (2015). Effect of biochar and cowdung on nodulation, growth and yield of soybean (Glycine max I. Merrill).
International Journal of Agriculture and Biosciences 4(4): 154-160.

Ali, M.M.E. (2018). Effect of plant residues derived biochar on fertility of a new reclaimed sandy soil and growth of wheat (Triticum aestivum L.). Egyption, Jour., of Soil Sci., 7 (58): 93103.

Amini, S. (2015). Carbon dynamics in salt-affected soils. Ph.D. Thesis Griffith School of Environment Science, Environment, Engineering and technology Griffith University.

AOAC (1995). Association of Official Analysis Chemists. Official Methods of Analysis", $15^{\text {Th }}$ ed., Washington, D.C., U.S.A.

Atkinson, C.J., J.D. Fitzgerald and N.A. Hipps (2010). Potential mechanisms for achieving agricultural benefits from biochar application to temperate soils: a review. Plant and Soil 337: 118.

Awad, E.M., E.A.A. Tartoura, H.M. El-Foly and A.l. Abdel-Fattah (2002). Response of potato growth, yield and quality to farmyard manure, sulphur and gypsum levels application. 2nd Inter. Conf. Hort. Sci., Kafr El-Sheikh, Tanta Univ. Egypt. p. 24-39.

Badawy, F.H., M.M.M. Ahmed, H.M. ELRewainy and M.M.A. Ali (2011). Response of wheat grown on sandy calcareous soils to organic manures and sulfur application. Egypt. J. Agric. Res., 89 (3): 785-807.

Balazs, H., O. Opara-Nadib and F. Beesea (2005). A simple method for measuring the carbonate content of soil. Soil Sci. Am. J., 69: 1066-1068.

Barnes, R.T., M.E. Gallagher, C.A. Masiello, Z. Liu and B. Dugan (2014). Biochar-induced changes in coil hydraulic conductivity and dissolved nutrient fluxes constrained by laboratory experiments. PLoS one, 9(9): e108340. 
Blake, G.R. and K.H. Hartge (1986). Bulk density," In: A. Klute, et al., Eds., Methods of Soil Analysis, Part I, ASA.

Brady, N.C. and R.R. Weil (2002). The Nature and Properties of Soils. 14th ed. Prentice Hall, Upper Saddle River, New Jersey.

Buchkina, N.P., R. Hüppi and J. Leifeld (2019). Biochar and short-term $\mathrm{N}_{2} \mathrm{O}$ and $\mathrm{CO}_{2}$ emission from plant residueamended soil with different fertilisation history. ZemdirbysteAgriculture, 106 (2): 99-106.

Bruun, E.W., H. Hauggaard-Nielsen, N. Ibrahim, H. Egsgaard, P.P. Ambus, P. Jensen and K. Dam-Johansen (2011). Influence of fast pyrolysis temperature on biochar labile fraction and shortterm carbon loss in a loamy soil. Biomass and Bioenergy 35: 11821189.

Chapman, H.D. and P.F. Partt (1961). Methods of analysis for Soils, Plants and Water Agric. Publ. University of California, Riverside.

Cottenie, A., M. Verloo, L. Kiek, G. Velghe and R. Camerlynek (1982). Chemical analysis of plants and soils Lab. Anal. and Agroch. State Univ., Ghent, Belgium.

Deekshitha, D.K.D., P. Ravindra Babu and P. Madhuvani (2017). Effect of fertilizer levels and sulphur on soil properties in clay loam soil. Plant Archives 17 (2): 846-850.

Dhage, S.J., V.D. Patil and M. J. Patange (2014). Effect of various levels of phosphorus and sulphur on yield, plant nutrient content, uptake and availability of nutrients at harvest stages of soybean [Glycine max (L.)]. Int., J., Curr., Microbiol., App., Sci., 3(12): 833-844.

Dos Passos, A.M.A., P.M. de Rezende, E. R. Carvalho, F. William and D. Ávila (2015). Biochar, farmyard manure and poultry litter on chemical attributes of a distrophic cambissol and soybean crop. Rev. Bras. Ciênc. Agrár. Recife, 10(3): 382-388.

Dume, B., T. Mosissa and A. Nebiyu (2016). Effect of biochar on soil properties and lead $(\mathrm{Pb})$ availability in a military camp in South West Ethiopia. Afr. J. Environ. Sci. Technol., 10(3): 77-85.

Egamberdieva, D., S. Wirth, U. Behrendt, E.F. Abd_Allah and B. Gabriele (2016). Biochar treatment resulted in a combined fffect on soybean growth promotion and a Shift in plant growth promoting rhizobacteria. Front. Microbiol. 7: 209.

El-Gamal, B.A.H. (2015). Effect of some soil amendments on soil conditions and plant growth. Ph.D Thesis, Depar., of S. Sci.,e Fac., of Agric., Menoufia Univ., Egypt.

El-Maddah, E.I., M.E.D. El-Sodany and A.A. Mahmoud (2012). Effect of different tillage systems and soil conditioners on some chemical properties and status of nutrients. Egypt of Appl. Sci., 27(12): 968-995.

El-Shouny, M.M. (2006). The effect of some soil amendments on soil properties and wheat production in salt affected soils. Minufiya J. Agric. Res., 31(4): 1105-1117.

El-Sodany, M.E.D., E.I. El-Maddah, A.A. Mahmoud and M.A. El-Altar (2012). Effect of planting methods, different tillage systems and soil conditioners on some properties and productivity of soils. Egypt. J. of Apple. Sci., 27(10): 660-693.

El-Tarabily, K.A., A.S. Abdou, E.S. Maher and M. Satoshi (2006). Isolation and characterization of sulfur-oxidizing bacteria, including strains of Rhizobium, from calcareous sandy soils and their effects on nutrient uptake and growth of maize (Zea mays L.). Aus J Agril Res 57(1): 101-111.

Erdem, H., M.B. Torun, N. Erdem, A. Yazıcı, I. Tolay, Gunal and F. Özkutlu (2016). Effects of different forms and 
doses of dulphur application on wheat. Turkish J. of Agri., - Food Sci. and Technology, 4(11): 957-961.

FAO (2011). The State of the World's Land and Water Resources for Food and Agriculture. Managing systems at risk. Rome.

FAO (2014). Diagnostic Horizons properties and materials. Lecture notes on the major soil of the world. Retrieved 14 June.

Ferreras, L., S. Gomez, S. Toresani, I. Firpo and R. Rotondo (2006). Effect of organic amendments on some physical, chemical and biological properties in a horticultural soil. Bioresour. Technol., 97: 635-640.

Gebremedhin, G.H., B. Haileselassie, D. Berhe and T. Belay (2015). Effect of biochar on yield and yield components of wheat and postharvest soil properties in Tigray, Ethiopia. J. of Fertilizers \& Pesticides. 6 (2): 2471-2728.

Gondek, K. and M. Kopeć (2010). Assessment of the effect of sulphur supplied to the soil with mineral fertilizers and waste from magnesium sulphate production on its content in spring wheat (Triticum aestivum L.) and in soil effluents. Polish J., of Agron., 2: 18-26.

Gupta, R.K., A. Hussain, S.S. Sooch and J.S. Kang (2019). Rice straw biochar improves soil fertility, growth, and yield of rice-wheat system on a sandy loam soil. Experimental Agriculture, 56(1): 118-131.

Hashemimajd, K., T.M. Farani and S.J. Somarin (2012). Effect of elemental sulphur and compost on electrical conductivity and phosphorus availability of one clay soil. African Journal of Biotechnology; 11(6): 14251432.

Helmy, A.M. and K. A. Shaban (2013). Wheat productivity and nutrients uptake after inhibitory soil salinity adverse by some sulfur sources. Egypt. J. Soil Sci. 53(2): 281-298.

Jamal, A., Y.S. Moon and M.Z. Abdin (2010). Sulphur -a general overview and interaction with nitrogen. Australian Journal of Crop Science. 4(7): 523-529.

Kaviani, B. and A. Kharabian (2008). Improvement of the nutritional value of soybean [Glycine max (L) Merr.] seed with alteration in protein subunits of glycinin (11S Globulin) and $\beta$-conglycinin (7S Globulin). Turkish J., of Biol., 32: 91-97.

Kaya, M., K. Zeliha and I. Erdal (2009). Effects of elemental sulfur and sulfur containing waste on nutrient concentrations and growth of bean and corn plants grown on a calcareous soil. Afr. J. Biotechnol. 8(18): 4481-4489.

Kizito, S., H. Luo, J. Lu, H. Bah, R. Dong and S. Wu (2019). Role of NutrientEnriched Biochar as a Soil Amendment during Maize Growth: Exploring Practical Alternatives to Recycle Agricultural Residuals and to Reduce Chemical Fertilizer Demand. Sustainability, 11(11): 3211.

Kookana, R.S., A. K. Sarmah, V. Zwieten, E. Krull and B. Singh (2011). Biochar application to soil: Agronomic and environmental benefits and unintended consequences. Advances in Agronomy 112: 103- 143.

Land Development Department (2010). Manual for Chemical Analysis for Soil, http://www.Idd.go.th/PMQA/2553/Manu al/ OSD-03.pdf, 25 April.

Leifeld, J., S. Siebert and I. KogelKnabner (2002). Biological activity and organic matter mineralization of soil amended with biowaste composts, J. Plant Nutr. Soil Sci. 165: 151-159.

Liu, X.H. and X. C. Zhang (2012). Effect of biochar on $\mathrm{pH}$ of alkaline soils in the Loess Plateau: Results from incubation experiments. International J., of Agriculture and Biol., 4: 745-750. 
Major, J., M. Rondon, D. Molina, S.J. Riha and J. Lehman (2010a). Maize yield and nutrition during 4 years after biochar application to a Colombian Savanna Oxisol. Plant Soil 333: 117128.

Major, J., J. Lehmann, M. Rondon and C.L. Goodale (2010b). Fate of soilapplied black carbon: downward migration, leaching and soil respiration. Global Change Biology 16: 1366-1379.

Malhi, S.S., J.J. Schoenau and C.A. Grand (2005). Review of sulfur fertilizer management for optimum yield and quality of canola in the Canadian Great Plains. Can J Plant Sci 85:297307.

Mishera, S.K., J.V. Tyagi and V.P. Singh (2003). Comparison of infiltration models. Hydrological Processes 17: 2629-2652.

Mousa, A.A. (2017). Effect of using some soil conditioners on salt affected soil properties and its productivity at ElTina Plain Area, North Sinai, Egypt. Egypt. J. Soil Sci., 57(1): 101 - 111.

Motior, R. M., A.A. Soaud, H. Fareed, A. Darwish and M. Sofian-Azirun (2011). Responses of sulfur, nitrogen and irrigation water on Zea mays growth and nutrients uptake. Austr., J., of Soil Sci., 5(3): 350-360.

Mutowal, W., S.G. Al-Solaimani and S.M. Ismail (2013). Effect of sulphur amendments levels on calcareous saline sodic soil and squash yield in saudi Arabia. Asian J. of Science and Techology 4 (12): 48-51.

Nabavinia, F., H. Emami, A. Astaraee and A. Lakzian (2015). Effect of tannery wastes and biochar on soil chemical and physicochemical properties and growth traits of radish. Int. Agrophys., 29: 333-339.

Nigussie, A., E. Kissi, M. Misganaw and G. Ambaw (2012). Effect of biochar application on soil properties and nutrient uptake of lettuces (Lactuca sativa) grown in chromium polluted soils. American-Eurasian J., of Agric., and Environm., Sc., 12: 369-376.

Pias, O.H.C., T. Tiecher, M. R. Cherubin, M. Mazurana and C. Bayer (2019). Crop yield responses to sulfur fertilization in Brazilian no-till soils: a systematic review. Revista Brasileira de Ciência do Solo, 43.

Rowell, D. L. (1995). Soil Science Methods \& Application Library of Congress Cataloging Publication Data, New York, NY10158. USA.

Prapagar, K., S.P. Indraratne and P. Premanandharajah (2012). Effect of soil amendments on reclamation of saline-sodic Soil. Tropical Agric., Rese., 23 (2): 168 -176.

Sangwan, A., B.S. Duhan and P.S. Sangwan (2018). Effect of different sources of sulphur on yield and nutrient uptake by wheat. Journal of Pharmacognosy and Phytochemistry, 7(6): 2686-2691.

SAS (2010). SAS Users guide, Statistics SAS, Inst. Gary, N.C., U.S.A.

Sharma, A. and S. Sharma (2014). Effect of nitrogen and sulphur nutrition on yield parameters and protein composition in soybean [Glycine max (L.) Merrill]. J., of Applied and Natural Sci., 6 (2): 402-408.

Sheldrick, B.H. and C. Wang (1993). Particle Size distribution. In: Soil Sampling and Methods of Analysis, Ed.: Carter, M.R. Canadian Society of Soil Science, Lewis Publishers, Ann Arbor, MI. pp 499-511.

Shenbagavalli, S. and S. Mahimairaja (2012). Characterization and effect of biochar on nitrogen and carbon dynamics in soil. J. Adv. Biol., Res., 2 (2): 249-255.

Sukartono Utomo, W.H., Z. Kusauma and W.H. Nugroho (2011). Soil fertility status, nutrient uptake and maize (Zea mays L.) yield following biochar and cattle manure application on sandy 
B. A. El-Gamal, et al.,

soils of Lombok, Indonesia. Journal of Tropical Agriculture. 49(1-2): 47-52.

Suman, J., B.S. Dwivedi, A.K. Dwivedi and S.K. Pandey (2018). Interaction effect of phosphorus and sulphur on yield and quality of soybean in a vertisol. Int. J. Curr. Microbiol., App. Sci 7(3): 152-158.

Suppadit, T., N. Phumkokrak and P. Poungsuk (2012). The effect of using quail litter biochar on soybean (glycine max [l.] merr.) production. Chilean J., of agric., Rese., 72(2): 244251.

Verheijen, F., S. Jeffery, A.C. Bastos, M. Van der Velde and I. Diafas (2010). Biochar application to soils: A Critical scientific review of effects of soil properties, processes and functions. JRC Scientific and Technical Reports, EUR 24099 01/2010; European Commission Publication Office, Luxembourg. assessment of some soils North Nile Delta, Egypt. Journal of American Science. 6(6): 156-161.

Wakode, H.B., D. Dutta, V.R. Desai, K. Baier and R. Azzam (2011). Morphometric analysis of the upper catchment of Kosi River using GIS techniques. Arabian J., of Geosciences 6: 395-408.

Xu, R., L. Ferrante, K. Hall, C. Briens and F. Berruti (2011). Thermal selfsustainability of biochar production by pyrolysis, J. Anal. Appl. Pyrol., 91(1): 55-59

Yooyen, J., S. Wijitkosum and T. Sriburi (2015). increasing yield of soybean by adding biochar. J. Environ. Res. Develop. 9 (4): 1066-1074.

Zhang, H., R. Paul Voroney, G.W. Price and A.J. White (2017). Sulfur-enriched biochar as a potential soil amendment and fertilizer. Soil Res., (55): 93 -99.

Wahab, M.A., M.A. Rasheed and R.A.

Youssef (2010). Degradation hazard

$$
\text { تأثير الكبريت والبيوشار علي خواص التربة وإنتاجية كل من القمح وفول الصويا }
$$

بشير أبو بكر الجمل(")، نجلاء إبراهيم خلف الله(؟)، محمد مصطفي الكفرراوي(')

$$
\text { (') (־مه بحوث الاراضي والمياة والبيئة-الجيزة-مصر }
$$$$
\text { الملخص العربى }
$$

أقيمت تجرية ليزيمترات بمحطة البحوث الزراعية بالجميزة التابعة لمركز البحوث الزراعية لدراسة تأثير الكبريت

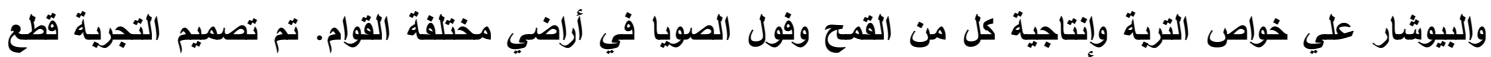

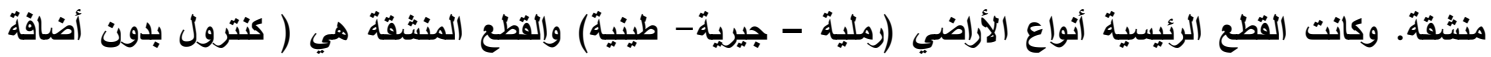

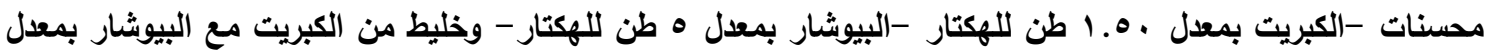
كبريت . ه. 1 طن للهكتار +ه طن بيوشارللاهكتار).

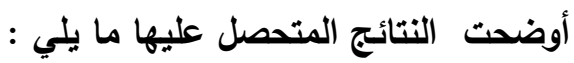


-أدت إضافة محسنات التربة إلي الاراضي مختلفة القوام إلي خفض كل من درجة تفاعل التربة والتوصيل الكهربي

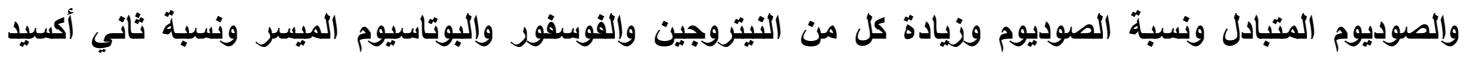

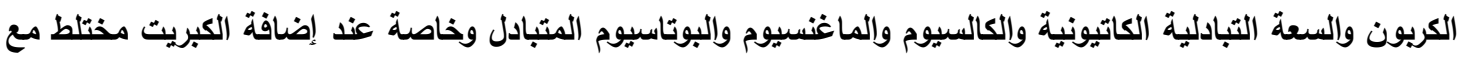
البيوشار ادي تحسين معنوي في الخواص الكيميائية مقارنة بياقي المعاملات الاخري.

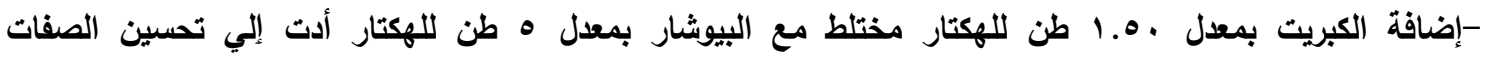

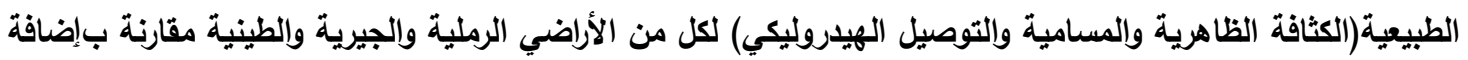
المحسنات منفرد أومعاملة الكنترول. - إضافة محسنات التربة منفردة أو مختلطة أدت إلي تحسين إنتاجية الأراضي المختلفة من محصول القمح وفول الصويا والمحتوي والممتص من النيتروجين والفوسفور والبوتاسيوم من نباتات القمح وفول الصويا مقارنة بالأراضي الغير معاملة بالمحسنات. توصي الدراسة:

نوصي بإضافة الكبريت مختلط مع البيوشار لتحسين الخواص الطبيعية والكيميائية للأراضي الرملية والجيرية والطينية ورفع إنتاجية القمح وفول الصويا والممتص من العناصر الغذائية.

السادة المحكمين

أ.د/ منصور الاسوقى السودانسى معهل بحوث الأراضى والمياه والبيئة - مركز البحوث الزراعية

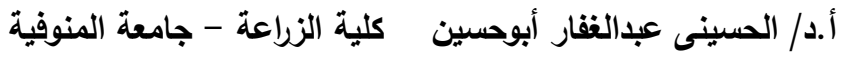

